\section{OPEN ACCESS}

Edited and reviewed by:

Ming Wang

Phanes Therapeutics, United States

${ }^{*}$ Correspondence:

Lili Wang

wangl/63@126.com

Specialty section:

This article was submitted to

Experimental Pharmacology and Drug

Discovery,

a section of the journal

Frontiers in Pharmacology

Received: 08 November 2017

Accepted: 20 November 2017

Published: 28 November 2017

Citation:

Chen W, Shui F, Liu C, Zhou X, Li W,

Zheng Z, Fu W and Wang L (2017)

Corrigendum: Novel Peripherally Restricted Cannabinoid 1 Receptor

Selective Antagonist TXX-522 with

Prominent Weight-Loss Efficacy in Diet Induced Obese Mice.

Front. Pharmacol. 8:890.

doi: 10.3389/fphar.2017.00890

\title{
Corrigendum: Novel Peripherally Restricted Cannabinoid 1 Receptor Selective Antagonist TXX-522 with Prominent Weight-Loss Efficacy in Diet Induced Obese Mice
}

\section{Wei Chen ${ }^{1,2}$, Fengchun Shui ${ }^{1,2}$, Cheng Liu $^{3}$, Xinbo Zhou ${ }^{1,2}$, Wei Li ${ }^{1,2}$, Zhibing Zheng ${ }^{1,2}$, Wei Fu ${ }^{3}$ and Lili Wang ${ }^{1,2 *}$}

\footnotetext{
${ }^{1}$ Beijing Institute of Pharmacology and Toxicology, Beijing, China, ${ }^{2}$ State Key Laboratory of Toxicology and Medical Countermeasures, Beijing, China, ${ }^{3}$ Department of Medicinal Chemistry, School of Pharmacy, Fudan University, Shanghai, China

Keywords: CB1R antagonist, obesity, periphery, blood-brain-barrier
}

\section{A corrigendum on}

Novel Peripherally Restricted Cannabinoid 1 Receptor Selective Antagonist TXX-522 with Prominent Weight-Loss Efficacy in Diet Induced Obese Mice by Xie, X., Chen, W., Zhang, N., Yuan, M., Xu, C., Zheng, Z., et al. (2017). Front. Pharmacol. 8:707. doi: 10.3389/fphar.2017.00707

There is an error in the Funding statement. The correct number for the Major Program of the Ministry of Science and Technology of China is 2012ZX09301-001, 2012ZX09301-003.

In the original article, we neglected to include the funder the National Natural Science Foundation of China, 81430090 to LW.

The authors apologize for these errors and state that this does not change the scientific conclusions of the article in any way.

Conflict of Interest Statement: The authors declare that the research was conducted in the absence of any commercial or financial relationships that could be construed as a potential conflict of interest.

Copyright $(2017$ Chen, Shui, Liu, Zhou, Li, Zheng, Fu and Wang. This is an open-access article distributed under the terms of the Creative Commons Attribution License (CC BY). The use, distribution or reproduction in other forums is permitted, provided the original author (s) or licensor are credited and that the original publication in this journal is cited, in accordance with accepted academic practice. No use, distribution or reproduction is permitted which does not comply with these terms. 